\title{
Sensor placement for soil water monitoring in lemon irrigated by micro sprinkler
}

\author{
$\overline{\text { Eugênio F. Coelho', Delfran B. dos Santos }{ }^{1} \text { \& Carlos A. V. de Azevedo }}{ }^{2}$
}

\begin{abstract}
This research had as its objective the investigation of an alternative strategy for soil sensor placement to be used in citrus orchards irrigated by micro sprinkler. An experiment was carried out in a Tahiti lemon orchard under three irrigation intervals of 1,2 and 3 days. Soil water potential, soil water content distribution and root water extraction were monitored by a time-domain-reflectometry (TDR) in several positions in soil profiles radial to the trees. Root length and root length density were determined from digital root images at the same positions in the soil profiles where water content was monitored. Results showed the importance of considering root water extraction in the definition of soil water sensor placement. The profile regions for soil water sensor placement should correspond to the intersection of the region containing at least $80 \%$ of total root length and the region of at least $80 \%$ of total water extraction. In case of tensiometers, the region of soil water potential above $-80 \mathrm{kPa}$ should be included in the intersection.
\end{abstract}

Key words: tensiometer, soil water content, soil water potential, irrigation management

\section{Posicionamento de sensores para monitoramento de água no solo em limoeiro irrigado por microaspersão}

\begin{abstract}
RESUMO
Este trabalho teve como objetivo investigar uma estratégia alternativa de posicionamento de sensores de água no solo, para uso em pomares de citros irrigados por microaspersão. Um experimento foi conduzido em um pomar de limão Tahiti, sob três intervalos de irrigação: 1, 2 e 3 dias. A distribuição de umidade, potenciais de água e extração de água do solo foram monitorados por um analisador de umidade de reflectometria no domínio do tempo (TDR) em várias posições, em perfis do solo radiais às plantas. Comprimento e densidade de raízes foram determinados a partir de imagens digitais nas mesmas posições onde a umidade fora monitorada. Os resultados mostraram a importância de se considerar a extração de água pelas raízes na definição da posição dos sensores de água do solo. As regiões do perfil para posicionamento de sensores de água do solo devem corresponder à interseção da região com pelo menos $80 \%$ do comprimento total das raízes e à região de ocorrência de pelo menos $80 \%$ da água total extraída no perfil. No caso de tensiômetros, a região de potenciais acima de -80 kPa deve ser incluída na interseção dessas regiões.
\end{abstract}

Palavras-chave: tensiômetro, umidade do solo, potencial de água do solo, manejo de irrigação 


\section{INTRODUCTION}

Sensors have been recommended for soil water monitoring for a long time all over the world (Campbell \& Campbell, 1982). Many kinds of sensors are available, however tensiometers, electrical resistance blocks for soil water potential, TDR (time domain reflectometry), surface capacitance insertion probes and neutron probes for soil water content have been the most common in field work. The use of sensors for soil water monitoring should take under considerations factors such as the number of stations for readings and their placement. The number of stations for monitoring is strongly dependent upon soil spatial variability and has been studied by some authors (Hendricks \& Wierenga, 1990, Doorembos \& Kassam, 1994). Stegman (1982) recommended the use of four stations for 65 ha. Schimitz \& Sourell (2000) compared the use of TDR to granular matrix sensors and found that the number of stations should be at least nine under uniform soil conditions.

Sensor placement is fundamental in soil water monitoring. A sensor installed in a soil zone without roots does not detect changes in water content as it would if installed in the zone of high root concentration. Sensor placement in soil wetted volume under irrigation depends upon soil flow conditions, i.e., the locations for sensors under one-dimensional flow (sprinkler irrigation) are different from the ones for sensors under three-dimensional flow (trickle irrigation). Under sprinkler irrigation (one-dimensional flow), the sensor placement should be limited to root distribution, since soil water content is uniform everywhere in the soil. Under trickle irrigation, sensor placement depends upon not only root distribution, but also water distribution in the wetted volume.

Sensor placement recommendations for soil water monitoring have been made on an empirical basis (Pogue \& Pooley, 1985). Sensors should be located at the upper and lower limits of the root water uptake zone (Haise \& Hagan, 1967) and should be located close to the emitter in case of drip irrigation (Phene \& Howell, 1984, Levin et al., 1985). Two sensors should be installed at different depths according to the root layer, where the deeper one should be twice the depth of the shallower (Stegman, 1982).

Soil water monitoring for fruit crop irrigated by trickle requires special care during sensor placement, because of the larger root volume of these crops and the uncertainty of locations of representative root activity zones. Few references have been found in this subject. Machado \& Coelho (2000) verified that tensiometers should be placed at distances from the plants of 25 to $75 \%$ of the canopy radius and at depths of 0-0.2, 0.2-0.4 and 0.4-0.6 m for 'Tahiti' lemon plant. They recommend that the first two layers should be used to indicate the irrigation moment and the third one to evaluate the irrigation water depth in soil. Oliveira (2001) has worked with mango, finding that soil water sensors should be located at 0 to $65 \%$ of canopy radius and at depths of $0-0.6 \mathrm{~m}$ and Santos (1997) has found the distances of 1.0 to $1.5 \mathrm{~m}$ from the plant and the depths of $0.2,0.4$ and $0.6 \mathrm{~m}$ as the adequate zone for tensiometer placement. These references were based upon the concepts of effective root depth, i.e., the limit depth of $80 \%$ of total roots (Arruda, 1989) and on the root effective distance, i.e., the limit distance of $80 \%$ of total roots (Vieira et al., 1996). This approach does not consider the root uptake zone, whose limits may be different from the ones of the effective root zone.

This work contributes to soil water monitoring in sprayer irrigated 'Tahiti' lemon by introducing an alternative strategy for defining zones of wetted volume for sensor placement. Besides the effective root distribution and soil water distribution, the alternative strategy includes the effective root uptake distribution in the wetted volume. It overlaps information about these three distributions in order to define zones of wetted volume more adequate for sensor placement for irrigation management purposes.

\section{MATERIAL AND METHODS}

The work was carried out in an orchard of Tahiti lemon five years old Citrumelo swingle rootstock, at $12^{\circ} 34^{\prime}$ S latitude and $40^{\circ} 01^{\prime} \mathrm{W}$ longitude. The local climate belongs to the BSwh class according to Koppen methodology. The Tahiti lemon plants had 4 x 7 m spacing and were irrigated by sprayers of $38 \mathrm{~L} \mathrm{~h}^{-1}$ installed at $0.2 \mathrm{~m}$ from plant. The soil was a sandyloam distrophic Yellow Latossol with the physical characteristics as shown in Table 1, and Figure 1 obtained according to EMBRAPA (1997).

Table 1. Soil physical characteristics of the experimental area, laçu, Bahia State, Brazil, 2001

\begin{tabular}{ccccccc}
\hline $\begin{array}{c}\text { Depth } \\
(\mathbf{m})\end{array}$ & \multicolumn{3}{c}{ Texture $\left.\mathbf{( g ~ k g - 1}^{-1}\right)$} & $\begin{array}{c}\text { Total } \\
\text { Porosity } \\
\left(\mathbf{m}^{3} \mathbf{~ m}^{-3}\right)\end{array}$ & $\begin{array}{c}\text { Bulk } \\
\text { Density } \\
\left(\mathbf{M g ~ m}^{-3}\right)\end{array}$ & $\begin{array}{c}\text { Particles } \\
\text { density } \\
\left(\mathbf{M g ~ m}^{-3}\right)\end{array}$ \\
$0-0.20$ & 771.60 & 91.80 & 136.60 & 0.413 & 1.46 & 2.51 \\
$0.20-0.40$ & 643.10 & 129.20 & 227.70 & 0.423 & 1.48 & 2.56 \\
$0.40-0.60$ & 592.50 & 145.10 & 262.40 & 0.397 & 1.52 & 2.52 \\
$0.60-0.80$ & 582.70 & 125.70 & 291.60 & 0.413 & 1.45 & 2.47 \\
\hline
\end{tabular}

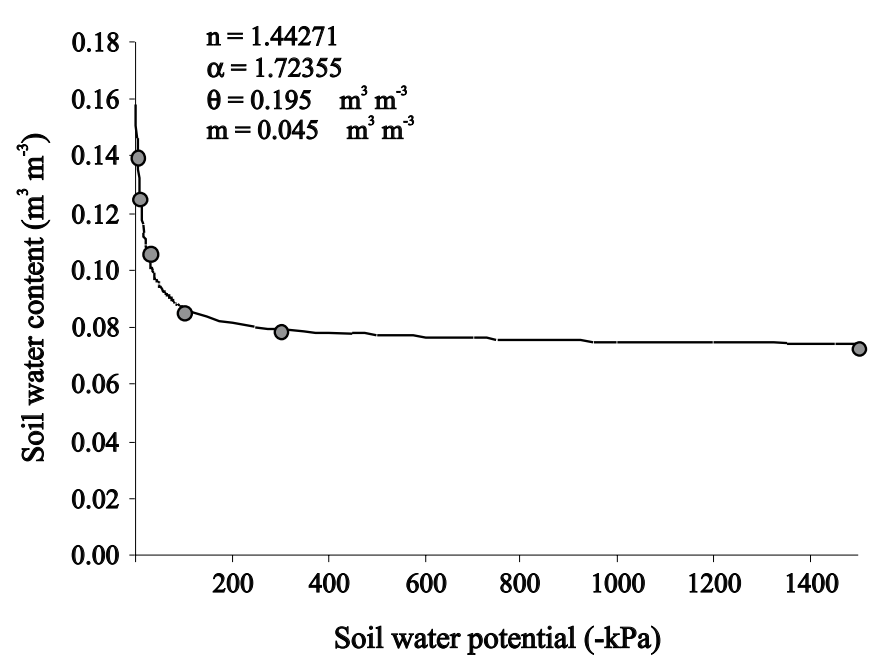

Figure 1. Soil water characteristic curve of the experimental area 
Three irrigation intervals (1, 2 and 3 days) were considered and two plants were used for each irrigation interval. The experiment was carried out during the fruiting phase and in October, when evapotranspiration reaches its highest values over the year. The amount of irrigation water was calculated based upon $100 \%$ of reference evapotranspiration (ETr), since there was no precipitation during the period. The irrigation times were calculated from the net application depth (ETr), an assumed application efficiency as $85 \%$ and the application intensity of the emitter. The data were collected during two irrigation cycles and the times of irrigation were $2 \mathrm{~h}$ and $30 \mathrm{~min}$ for one-day irrigation intervals, $4 \mathrm{~h}$ and $20 \mathrm{~min}$ for two-day irrigation intervals and $6 \mathrm{~h}$ and $30 \mathrm{~min}$ for three-day irrigation intervals.

\section{Soil water distribution and root water extraction}

TDR wave-guides were inserted in two soil profiles for each plant. One profile was in a longitudinal direction and the other in an orthogonal direction to plant row. The waveguides were installed at a horizontal distances from the plant of $0.15,0.25,0.50,0.75,1.0,1.5,2.0$ and $2.5 \mathrm{~m}$; at depths of $0.15,0.25,0.50,0.75,1.0$ and $1.2 \mathrm{~m}$. Small containers of $0.5 \mathrm{~L}$ capacity were located at the same horizontal distances from the plant to collect the water distribution over the soil surface during the irrigation event. After the irrigation event, the soil was covered by a plastic sheet to avoid soil evaporation. Soil water content data were collected in all profiles immediately before and after irrigation and at the end of the day. Deep percolation was monitored by soil water content variation at deeper positions in the soil profiles $(1.2 \mathrm{~m})$, mainly close to the emitter. Root water extraction at a location (r, z) between two irrigation events was computed by the difference between water content at a time $\mathrm{j}$ after an irrigation event and at a time $\mathrm{j}+1$ before the next irrigation event (Coelho \& Or, 1996; Coelho \& Or, 1999):

$$
\tau=\theta_{\mathbf{j}}-\theta_{\mathbf{j}+1}
$$

where,

$$
\begin{gathered}
\tau(\mathrm{r}, \mathrm{z}) \text { - water extracted by unit soil volume by roots, } \\
\mathrm{m}^{3} \mathrm{~m}^{-3} \\
\begin{aligned}
\theta_{\mathrm{j}}- & \text { Soil water content immediately after irrigation, } \\
& \mathrm{m}^{3} \mathrm{~m}^{-3}
\end{aligned} \\
\theta_{\mathrm{j}+1}-\text { Soil water content before next irrigation, } \mathrm{m}^{3} \mathrm{~m}^{-3}
\end{gathered}
$$

\section{Root Distribution}

Blocks of soil samples of $0.10 \times 0.10 \times 0.05 \mathrm{~m}$ were collected at the same positions in the profiles where wave guides were inserted. Samples were collected from the soil surface to the depth of $1.2 \mathrm{~m}$ and from the plant to a horizontal distance of $2.5 \mathrm{~m}$ away. Roots were separated from soil by a washing process (Bohm, 1979) and recorded using a 600 DPI resolution scanner. They were digitized to TIFF (Tagged Image File Format) image files. Length, diameter and area of roots were estimated using the Rootedge software package (Kaspar \& Ewing, 1997). Root length density (RLD) values were computed by:

$$
\mathrm{RLD}=\frac{\mathrm{L}_{\mathrm{R}}}{\mathrm{V}_{\mathrm{R}}}
$$

where,

$$
\begin{aligned}
& \text { RLD - root length density, } \mathrm{m} \mathrm{m}^{-3} \\
& \mathrm{~L}_{\mathrm{R}} \text { - Total root length of the sample, } \mathrm{m} \\
& \mathrm{V}_{\mathrm{R}} \text { - total volume of the sample, } \mathrm{m}^{3}
\end{aligned}
$$

\section{RESULTS AND DISCUSSION}

The definition of appropriate locations for sensor placement should be a result from evaluation of soil water potential distribution, root distribution and water extraction by roots in the wetted volume under the sprayer.

\section{Soil water distribution}

Figure 2 depicts soil water potential distribution in the wetted volume after irrigation for 1, 2 and 3-day irrigation intervals. The size of the wetted volume varied according to

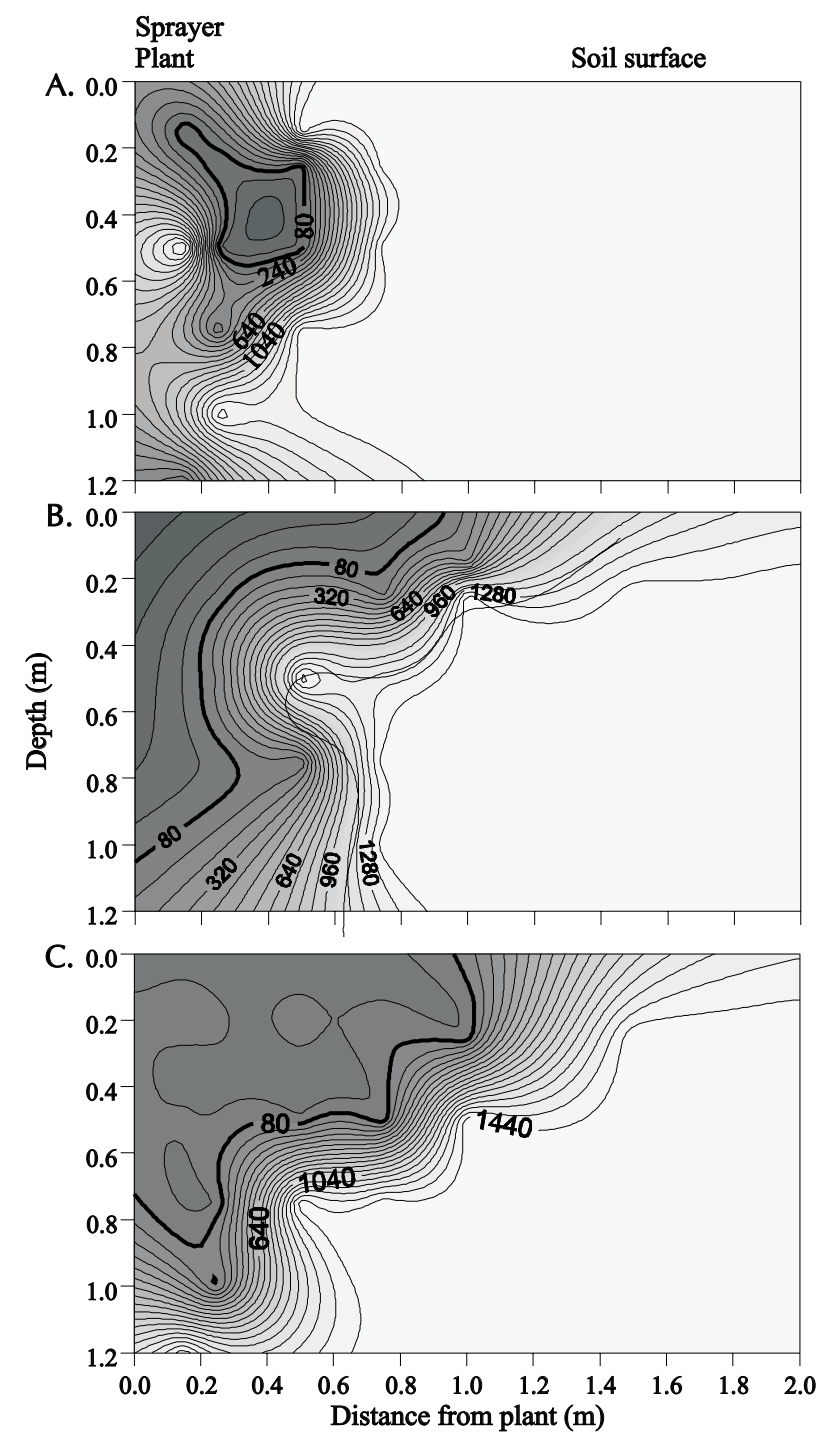

Figure 2. Soil water potential distribution $(-\mathrm{kPa})$ in the wetted volume under three irrigation intervals: (A) one day, (B) two days and (C) three days 
the amount of applied water. The larger the amount of applied water, the larger the depth of wetted volume and regions of high water potentials.

The irrigation water reached distances of $2.5 \mathrm{~m}$ from the sprayer at the soil surface. However, the zone of water potentials equal or larger than $-80 \mathrm{kPa}$ was limited to horizontal distances from the sprayer of equal or less than $1.0 \mathrm{~m}$ and to depths of less than $1.1 \mathrm{~m}$ for the three irrigation intervals. In the majority of the profiles the horizontal distance of $1.0 \mathrm{~m}$ limited the region of potentials to equal or larger than $-80 \mathrm{kPa}$.

These results are justified by the fact that 80 to $95 \%$ of water emitted by the sprayer infiltrated into the soil at a maximum distance of $1.5 \mathrm{~m}$ from it (Figure 3). The amount of water that reached the soil beyond this distance was not enough to raise the water content to soil water availability. Some of this water could have been evaporated even before having infiltrated into the soil.

A.

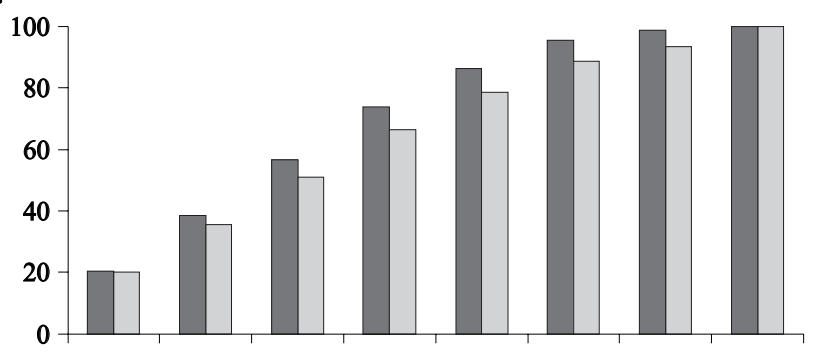

B.

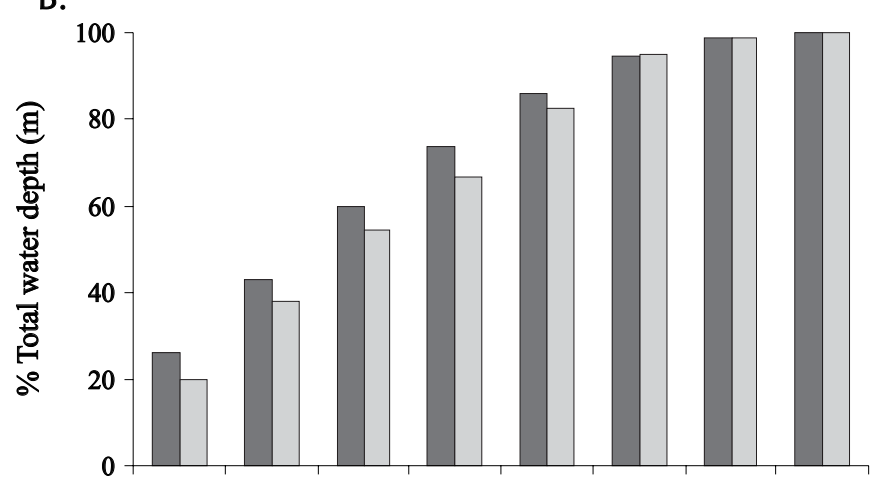

C.

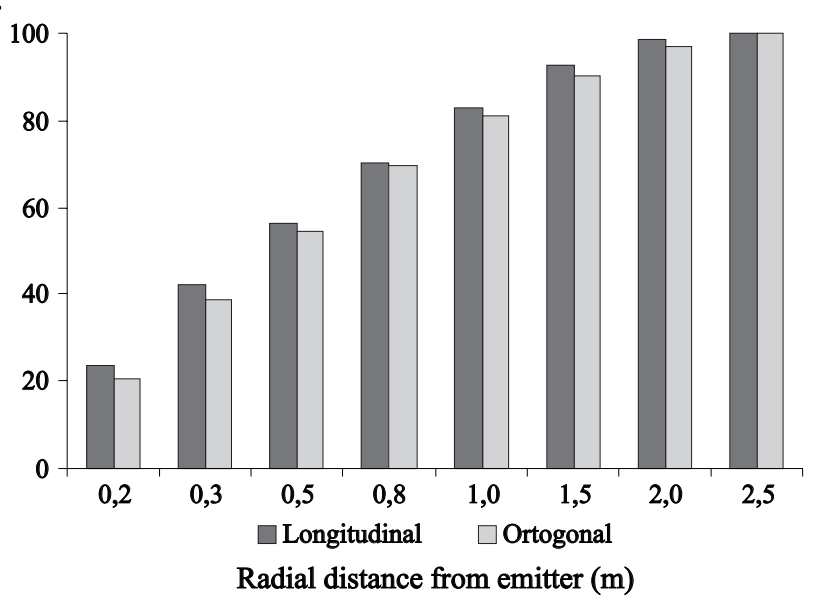

Figure 3. Soil surface water distribution from irrigation for three irrigation intervals: (A) one day, (B) two days and (C) three days

\section{Root distribution}

In this work the concept of effective root depth, DPe, , was used. This is the depth of the soil profile that contains $80 \%$ of total root length (Arruda, 1989). Also used was the concept of effective root distance, DTe. This is the distance from plant that contains $80 \%$ of total root length (Vieira et al., 1996). 82.3 to $84.7 \%$ of the total root length was found in the shallow soil layer $(0-0.25 \mathrm{~m}$ depth) and 84.1 to $85.8 \%$ was found up to $1.0 \mathrm{~m}$ from the plant in the profiles longitudinal and orthogonal to plant row for one-day irrigation interval (Figure 4A and B). The larger RLD values were found at depths of 0 to $0.25 \mathrm{~m}$ and at distances of 0 to $1.5 \mathrm{~m}$ from the plant.

In the case of the two-day irrigation interval, 86.2 to $87.5 \%$ of total root length was found at depths of 0 to $0.25 \mathrm{~m}$, and 78.9 to $80.8 \%$ at distances less than $1.0 \mathrm{~m}$ from the plant in the profiles longitudinal and orthogonal to plant row (Figure 4C and D). The larger RLD values were found in the zone limited by 0 to $1.7 \mathrm{~m}$ of horizontal distance from plant at $0-0.2 \mathrm{~m}$ depths.

In the case of the three-day irrigation interval (Figure 4E and F), 85.9 to $92.1 \%$ of total root length was found at depths of less than $0.5 \mathrm{~m}$, and 83.6 to $89.6 \%$ at distances less than $1.5 \mathrm{~m}$ from plant in the profiles orthogonal and longitudinal to plant row. Larger RLD values were found at 0-0.3 m depths in the soil profile, at distances from plants of 0 to $2.1 \mathrm{~m}$. The occurrence limits of at least $80 \%$ of total roots at distances 0 to $1.0 \mathrm{~m}$ from the plant coincides with the occurrence limits of $80 \%$ of total applied water over the soil surface by the sprayer for 1 and 2-day irrigation intervals. In the case of the three-day irrigation interval, these occurrence limits extended laterally giving space for root development.

\section{Root water extraction}

Root water extraction was observed all over the region of soil profile corresponding to depths of 0 to $0.8 \mathrm{~m}$ and at distances from the plant of 0 to $0.7 \mathrm{~m}$ during one irrigation cycle for one-day irrigation interval. The zone of largest extraction occurred for distances of 0 to $0.3 \mathrm{~m}$ from the plant and depths less than $0.5 \mathrm{~m}$ (Figure 5A). For the two-day irrigation interval, root water extraction was more pronounced in the zone of the soil profile limited by the distance of $0.5 \mathrm{~m}$ from the plant and $0.5 \mathrm{~m}$ from the soil surface (Figure 5B), but it occurred all over the region of soil profile in the $1.2 \mathrm{~m}$ from the plant and at $0-0.8 \mathrm{~m}$ depth. The root water extraction was observed at 0 to $1.1 \mathrm{~m}$ depths for distances 0 to $0.5 \mathrm{~m}$ from the plant and at depths less than $0.5 \mathrm{~m}$ for distances $0.5 \mathrm{~m}$ to $1.5 \mathrm{~m}$ from the plant (Figure 5C) for the threeday irrigation interval.

Results showed that root activity intensity reduced as the distance from the sprayer increased. Eighty percent of total root water extraction occurred at distances of 0 to $1.2 \mathrm{~m}$ from the plant where $80 \%$ of the total water applied over the soil surface by the sprayer was verified. Ninetyfive percent of total applied water over the soil surface occured at distances of 0 to $1.5 \mathrm{~m}$ from the emitter. 
A.
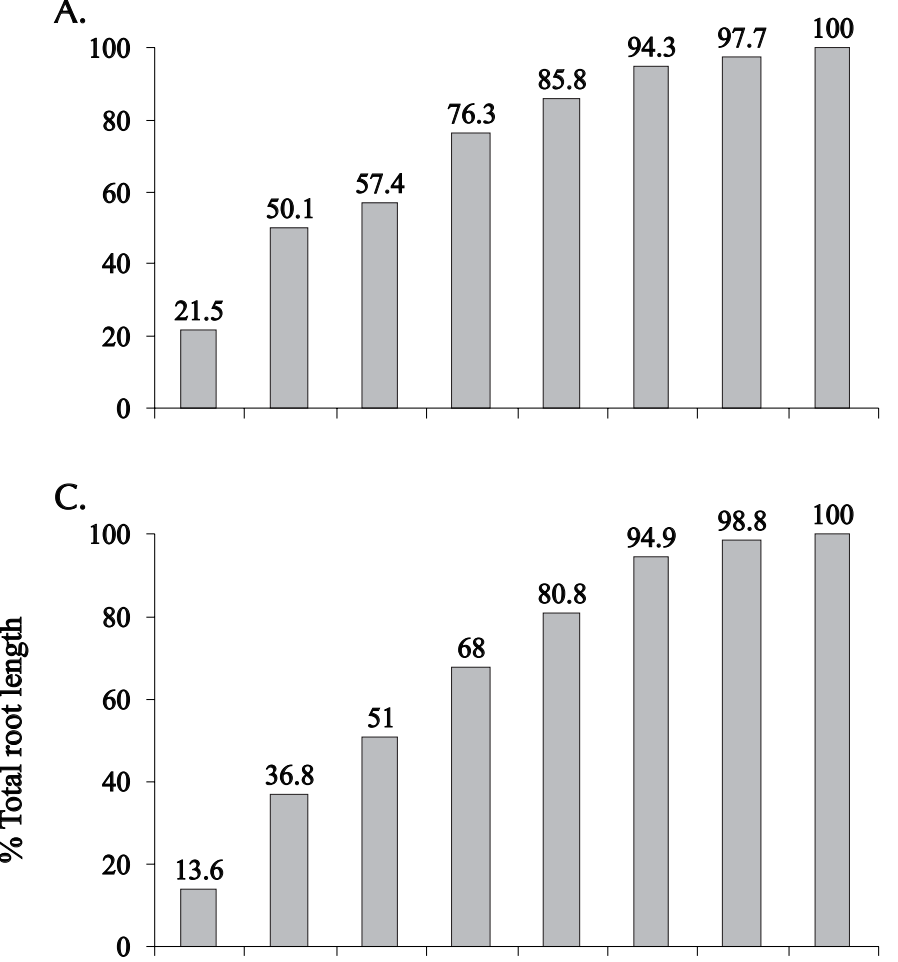

E.

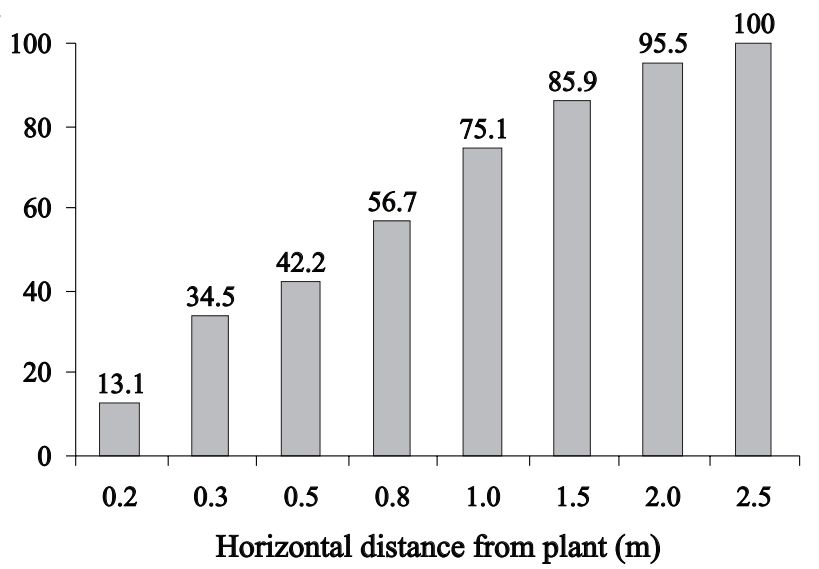

B.

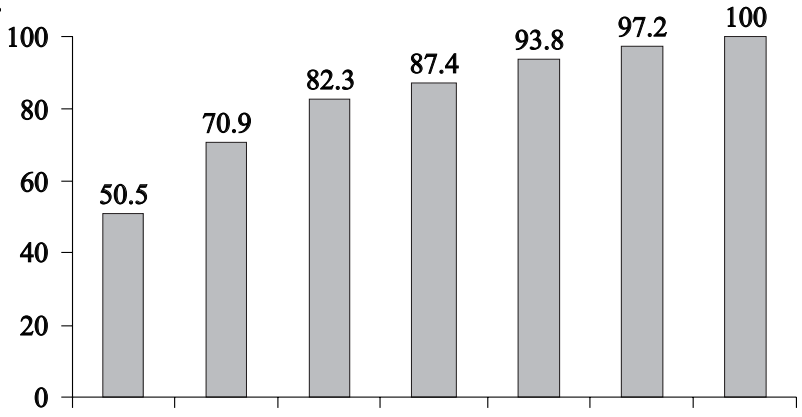

D.

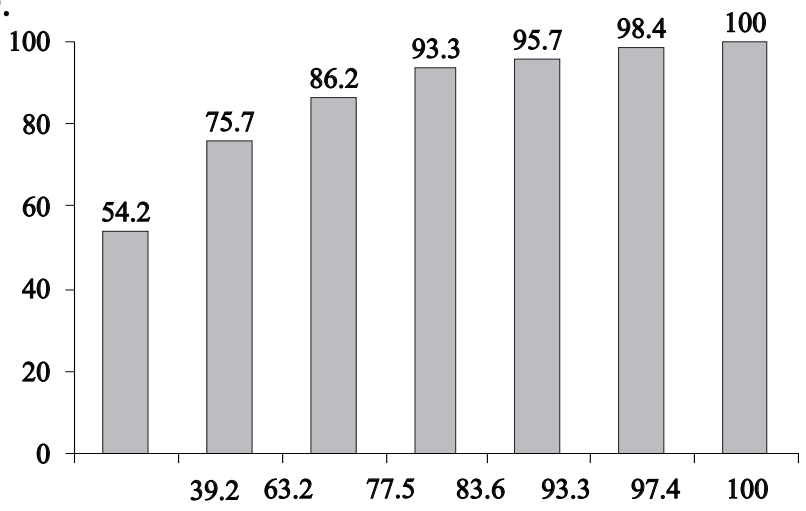

F.

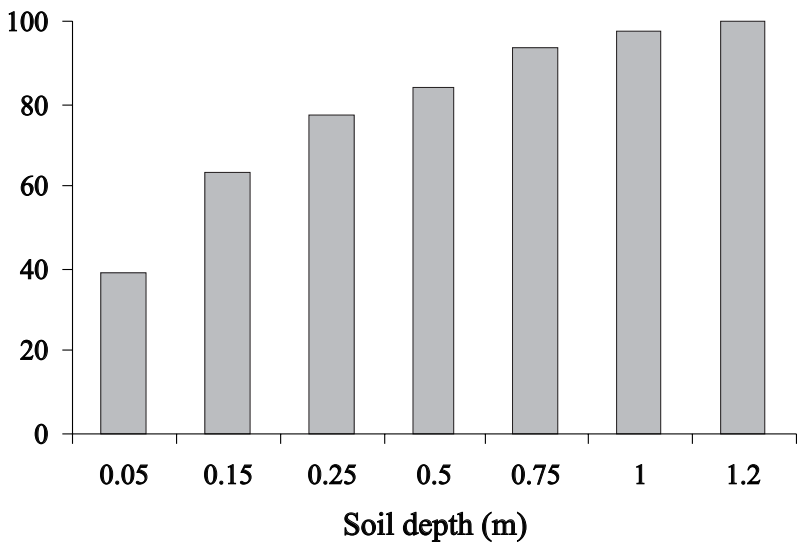

Figure 4. Percentage of total root distribution of 'Tahiti' Acid Lemon in a profile longitudinal and orthogonal to plant row for one (A, B), two (C, D) and three-day irrigation intervals $(E, F)$

\section{Sensor placement in the wetted volume}

The evaluation of soil water potential distribution by itself is not enough to define the positions for installing soil water sensors, especially tensiometers. The zones of soil water potential larger than $-80 \mathrm{kPa}$ and the zones of larger root water extraction have not coincided with each other for all of the irrigation intervals. There were zones of soil water potential above $-80 \mathrm{kPa}$ without significant root activity and zones of large root activity and soil water potentials smaller than $-80 \mathrm{kPa}$. Also the zones of soil water potential above $-80 \mathrm{kPa}$ have not coincided to the ones with $80 \%$ of total root length and the regions of high root activity have not coincided to the ones of larger RLD (above 80\%).

The distances from plants that limited the zones of larger RLD were superior to the ones that limited the zones of larger root water extraction. The depths of zones of high root water extraction were superior to those of high RLD, mainly close to the plant. The adequate positions for installing soil water sensors should be the zones of the wetted volume, in which variations in water content are highly sensitive to root water extraction. These regions associated with larger RLD corresponded to the zones of effective extraction. The time-response of soil water sensors will be more accurate in these zones, and as a consequence, irrigation will be applied at the right time. The region of larger root water extraction (at least $80 \%$ of total water extracted) is dynamic, i.e., it might change position according to variations of water content in the wetted volume. The region of larger root concentration (80\% of total roots) is static in a specific phase of the crop cycle. The intersection of these two regions results in a more adequate and safer region for soil water sensor placement. 

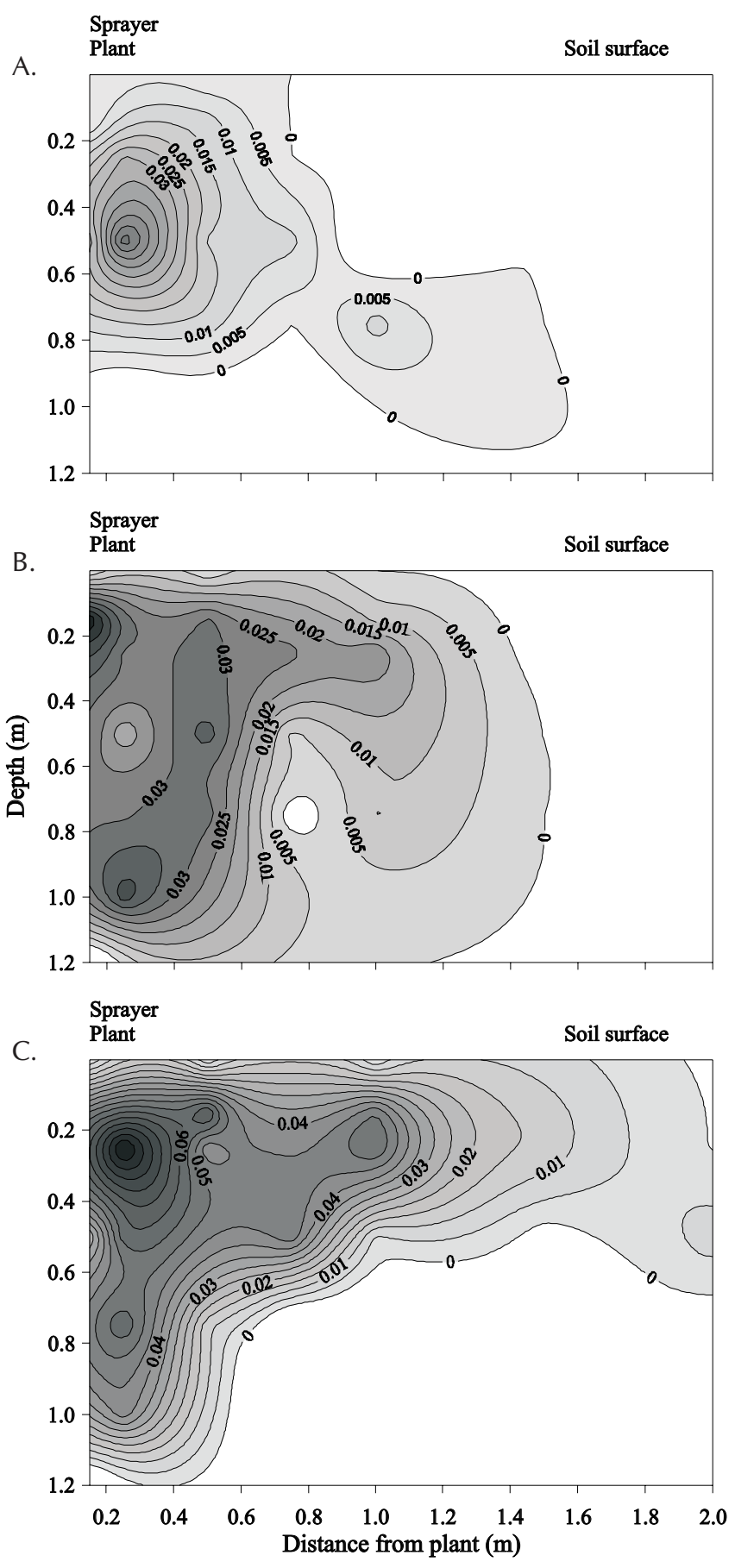

$\overline{\text { Figure 5. Root water extraction distribution, }\left(\mathrm{m}^{3} \mathrm{~m}^{-3}\right) \text {, in the wetted volume }}$ under one (A), two (B) and three-day irrigation interval (C)

This approach suggests the concepts of effective depth and distance of root water extraction (PEe and DEe ) as the depth from soil surface and distance from plant, respectively, where at least $80 \%$ of total root water extraction is found. Therefore, the intersection of the region that limits $80 \%$ of total root length and the region that limits $80 \%$ of total water extracted should be assumed as the most adequate for sensor placement and soil water monitoring for irrigation scheduling purposes. The zones of this intersection where soil water potentials are equal or more than $-80 \mathrm{kPa}$ become the most adequate for tensiometer placement.
If effective root depth (DPe) and distance (DTe) are taken as a basis in order to define the best region for sensor placement, then soil water sensors should be installed at distances from plants of less than $1.0 \mathrm{~m}$ and at a maximum depth of $0.25 \mathrm{~m}$ for irrigation frequencies of 1 and 2 days. These sensors should be installed at distances of $1.5 \mathrm{~m}$ from plant and at a maximum depth of $0.5 \mathrm{~m}$ for three-day irrigation frequency. On the other hand, if the intersection of the regions limited by (DTe, DPe) and (DEe, PEe) are taken as a basis, the most adequate and safer regions for sensor placement should be those limited by the distance from plants of $0.4 \mathrm{~m}$ and by the soil depth of $0.25 \mathrm{~m}$ for the one-day irrigation interval; by the distance of $0.5 \mathrm{~m}$ and by the depth of $0.25 \mathrm{~m}$ for the two-day irrigation interval and by the distance of $1.1 \mathrm{~m}$ and depth of $0.5 \mathrm{~m}$ for the three-day irrigation interval. The differences of the limits of the regions for sensor placement based upon the two approaches (using DPe, DTe and the intersection of DPe, DT and DEe, PEe) were not small. A sensor placed in a zone limited by DTe - DPe may not respond suitably to plant water needs if it is not also in the zone limited by DEe - PEe where water is being extracted. As a result, sensor time-response is going to be larger than it should be and irrigation may not be applied at the right moment.

\section{CONCLUSIONS}

1. The distance from plants and depths of effective root water extraction should be considered for soil water sensor placement definition.

2. The region of soil wetted volume under the sprayer that is more adequate and safer for soil water sensor placement should correspond to the intersection of the region containing at least $80 \%$ of total root length and the region of at least $80 \%$ of total water extraction. In the case of tensiometers, the region of soil water potential above $-80 \mathrm{kPa}$ should be included in the intersection.

\section{LITERATURE CITED}

Arruda, F. B. Necessidade de água nas culturas - Elementos de projeto. In: Curso Prático Internacional de Agrometeorologia para Otimização da Irrigação, 3., 1989, Campinas: IAC, 1989. 35p.

Bohm, W. Methods of studying root systems. New York: Springer Verlag, 1979. 190p.

Campbell, G. S.; Campbell, M. D. Irrigation scheduling using soil moisture measurements: theory and practice. In: Hillel, D. (ed.) Advances in Irrigation, New York: Academic Press, 1982. Cap. 2, p.25-42

Coelho, E. F.; Or, D. A parametric model for two-dimensional water uptake by corn roots under drip irrigation. Soil Science Society of America Journal. Madison, v.60, p.1039-1049, 1996.

Coelho, E. F.; Or, D. Modelo de distribuição de água e de potencial matricial no solo sob gotejamento com extração de água por raízes. Pesquisa Agropecuária Brasileira. Brasilia, v.34, n.2, p.225-234, 1999.

R. Bras. Eng. Agríc. Ambiental, v.11, n.1, p.46-52, 2007. 
Doorenbos, J.; Kassam, A. H. Efeitos da água no rendimento das culturas. Campina Grande: UFPB, 1994. 212 p. Estudos FAO: Irrigação e Drenagem, 33

Haise, H. R.; Hagan, R. M. Soil, plant and evaporative measurements as criteria for scheduling irrigation. In: Hagan, R. M., Haise, H. R., Edminster, T. W. Madison (ed.) Irrigation of agricultural lands. American Society of Agronomy, 1967. p.577604.

Hendrickx, J. M. H.; Wierenga, P. L. Variability of soil water tension in a trickle irrigated field. Irrigation Science, Berlin, v.11, p. 23-30, 1990.

Levin, I.; Sarig, S.; Meron, M. Tensiometers location in controlled automated drip irrigation of cotton. In: Proc. of the Third International Drip/Trickle Irrigation Congress... Fresno, 1985, p.782-785.

Kaspar, T. C.; Ewing, R. P. Rootedge: Software for measuring root length from desktop scanner images. Agronomy Journal, Madison, v.89, p.932-940, 1997.

Machado, C. C.; Coelho, R. D. Estudo da distribuição espacial do sistema radicular do limão "Cravo" enxertado com lima ácida “Tahiti”. Laranja, Cordeirópolis, v.21, n.2, p.359-380, 2000.
Oliveira, F. C. Uso e manejo da água na produção de manga sob condições subúmidas no estado do Piauí. Cruz das Almas: UFBA, 2001. 99p. Dissertação Mestrado

Phene,C. J.; Howell, T. A. Soil sensor control of high-frequency irrigation systems. Transaction of the ASAE, St. Joseph, v.27, p.392-396, 1984.

Pogue, W. R.; Pooley, S. G. Tensiometric management of soil water. In: Proc. of the Third International Drip/Trickle Irrigation Congress, Fresno, p.761-766. 1985.

Santos, C. A. S. Distribuição espacial e absorção de água pelo sistema radicular da cultura da manga (Mangifera indica L) irrigada por microapersão. Piracicaba: ESALQ-USP, 1997. 51p. Dissertação Mestrado

Schmitz, M.; Sourell, H. Variability in soil moisture measurements. Irrigation Science, Berlin, v.19, p. 147-151, 2000.

Stegman, E. C. Irrigation water management. In: Jensen, M. E. (ed.). Design and operation of farm irrigation systems. St. Joseph: American Society of Agricultural Engineers, 1982. p.763-816.

Vieira, D. B.; Genovez, A. M.; Gomes, E. M. Determinação da profundidade efetiva do sistema radicular do milho (Zea mays L.) irrigado. In: Congresso Nacional de Irrigação e Drenagem, 11., 1996, Campinas. Anais... Campinas: IAC, 1996. p.95-106. 